Article

\title{
Poverty and Economic Growth in Mexico
}

\author{
Jorge Garza-Rodriguez \\ Department of Economics, Universidad de Monterrey, 66238 San Pedro Garza García, Mexico; \\ jorge.garza@udem.edu; Tel.: +52-818-215-1455
}

Received: 22 August 2018; Accepted: 28 September 2018; Published: 30 September 2018

check for updates

\begin{abstract}
The relationship between poverty and economic growth has been widely discussed in the economic development literature during the past few decades. However, most of this research has been based on cross-sectional studies and very few studies have used time-series techniques to analyze this important issue. At the same time, there are also only a few studies analyzing this issue for the case of Mexico. Therefore, the objective of this paper was to analyze the relationship between poverty and economic growth in Mexico, using a cointegration analysis with structural change for the period 1960-2016. The Gregory-Hansen cointegration test confirmed the existence of a long-term equilibrium relationship between poverty reduction and economic growth, both in the short run and in the long run. Using a Vector Error Correction Model (VECM), we find that, in the long run, a $1 \%$ increase in economic growth leads to a $2.4 \%$ increase in per capita consumption (and therefore poverty reduction). This estimate is similar to those obtained in other studies for the case of Mexico and for other developing countries. Also, using the Granger causality test, it was found that there is a bidirectional causality relationship between poverty reduction and economic growth in Mexico.
\end{abstract}

Keywords: poverty; economic growth; economic development; Mexico

\section{Introduction}

For several decades one of the most important issues of the field of economic development has been whether economic growth necessarily leads to the reduction of poverty. Since the 1970s, Seers (1969) postulated that if poverty has not decreased in a given country we cannot say that that country has experienced economic development at all. Also, the hypothesis of the trickle-down effect or, expressed in another way, the hypothesis that "a rising tide lifts all boats" has been widely used since the early 1960s (Kakwani and Pernia 2000).

However, after much research carried out in the last two decades, the generally accepted view among economists is that economic growth bears an inverse relationship with poverty (Dollar and Kraay 2002; Alvaredo and Gasparini 2015; Ravallion and Datt 2002, among others) and currently the discussion focuses only on determining how strong the effect of growth on poverty is, that is, the magnitude of the elasticity of poverty with respect to growth. There is also much discussion in research on this subject about the effect that the pattern and structure of growth have on poverty (Thorbecke 2013). On the other hand, Adams (2004) points out that the effect of economic growth on poverty depends very much on how it is measured, finding that if it is measured by household income surveys, the effect is much greater than if measured through national accounts.

Another factor widely discussed in the literature is the effect of income distribution on poverty. Including this effect with the economic growth factor, Bourguignon (2004) proposed the existence of a poverty-growth-inequality triangle, by virtue of which these three variables are indissolubly related. Although prior to the publication of this article it was already known that poverty depended on growth and changes in the distribution of income, Bourguignon's contribution lies in pointing out that growth can be influenced by the degree of inequality and vice versa and that both factors affect poverty. 
In one of the most recent studies, Fosu (2017) conducts an analysis for 123 countries, finding that there is much variability in the response of poverty to both economic growth and inequality. In line with the findings of the consensus (e.g., Dollar and Kraay 2002), this author finds that economic growth has been the main factor that explains both increases and decreases in poverty for this large group of countries. However, interestingly, the author finds that there are strong regional differences and among countries in this regard. Although for most countries and regions income is the fundamental variable to explain changes in poverty, inequality plays a very important role in many countries. Another important finding of this study is that the poverty-inequality elasticity tends to be greater than the poverty-income elasticity, which indicates that changes in inequality can have very important effects on poverty.

Most research on the link between growth and poverty has been based on cross-sectional country data, which naturally makes it difficult to generalize the findings found to a particular country. Thus, the broad policy implications of these studies are hardly directly applicable to any given country (Besley and Burgess 2003). Another problem with cross-sectional-based research is that it is generally based on poverty lines appropriate for each country, which are not readily comparable across countries due to differences in household surveys on which they are based, the living standards indicators used and in the real values of the poverty lines (Ravallion 1995). Thus, there is very little research on this topic based on time-series data for a single country, such as Odhiambo (2009); Mulok et al. (2012); Abosedra et al. (2016) and Nyasha et al. (2017), who use modern time-series techniques to analyze this problem in different countries.

In the case of Mexico, there are very few studies (Hernández-Laos 2010; Esquivel 2015; and Campos Vázquez and Monroy-Gómez-Franco 2016) that have been carried out on this topic and, to my knowledge, there is none using modern time-series analysis. Thus, this paper intends to contribute to the scarce international literature, especially for the case of Mexico.

The results obtained in the paper indicate that, in the Mexican case, there is a positive and statistically significant effect of economic growth on the reduction of poverty, both in the long run as in the short run. According to the results obtained in the econometric model developed in the paper, a 1 per cent increase in economic growth leads to a $2.4 \%$ increase in per capita consumption. The Granger causality tests undertaken in the analysis showed that there is a bidirectional relationship of causality between economic growth and the reduction of poverty. These results are similar to the findings obtained in other studies.

The rest of the paper is organized as follows: in Section 2 a literature review is carried out, section three briefly explains the database used in the research, the fourth section explains the econometric methodology used, while section five shows and analyzes the econometric results obtained in the paper and the last section concludes.

\section{Literature Review}

As noted in the introductory section, the consensus among economists today is that economic growth has a positive effect on poverty reduction, so nowadays research focuses mostly on estimating the magnitude of this effect, that is to say, in estimating the elasticity of poverty with respect to growth. The literature on the estimation of this elasticity is quite broad. In a comprehensive study, Alvaredo and Gasparini (2015), using information for 76 developing countries for the period 1981-2010 find a growth elasticity of poverty equal to -1.53 when they use per capita consumption to measure growth and a growth elasticity of poverty of -1.46 when they use per capita income. These elasticities are much lower than those reported by Ravallion and Chen (1997), who estimated a poverty-growth elasticity of -3.1 for a sample of 67 countries for the period 1981-1994. However, the values estimated by Alvaredo and Gasparini (2015) are in line with the values estimated by other authors, such as Bourguignon (2003), who estimates it at -1.6, Ferreira and Ravallion (2011), who estimate it at -1.8 and Ravallion (2012) who estimates it at -1.4. 
In a recent study for a sample of 123 developing countries Fosu (2017) finds that, for the period 1981-2007, the growth elasticity of poverty was -2.3 , but with a large variation between regions, from -1.3 for Sub-Saharan Africa, down to -3.7 for the Europe and Central Asia region.

Another important conclusion of the literature is that the higher the inequality, the lower the poverty-growth elasticity. For example, for a sample of 47 developing countries in the 1980s and 1990s, Ravallion (2001) finds that, for countries that grew but that whose inequality also increased, the poverty rate dropped by an average of $1.3 \%$ per year, while for those which grew but their inequality decreased their poverty rate dropped seven times more, $9.6 \%$ per year. Perhaps more dramatic, this same author finds that for countries whose economies contracted during the period and whose inequality increased, their poverty rate increased by 14 percent per year, while if inequality decreased, poverty increased less than 2 percent per year. Bourguignon (2003) finds similar evidence for a sample of 114 growth spells in the 1980s and 1990s in 26 developing countries, finding that the growth elasticity of poverty increases (in absolute value) from 1.6 to 2 when he controlled for changes in the Gini index.

In addition to the fact that the growth elasticity of poverty decreases when the distribution of income worsens, it also decreases when initial poverty is greater. Thus, Ravallion (2012) finds that the growth elasticity of poverty decreases (in absolute terms) of about 2.1 when the poverty rate is 10 percent to 0.5 when the poverty rate is 80 percent.

Adams (2004), for a sample of 60 developing countries, finds that when economic growth is measured through the income reported in household surveys the growth elasticity of poverty (for the whole sample but excluding Eastern Europe and Central Asia) is -2.8, while when income is measured by national accounts (Gross Domestic Product (GDP) per capita) the growth elasticity of poverty is not statistically significant.

As discussed in the introduction, most of the literature on this topic has been based on cross-sectional studies for groups of countries, while research on time series by country has been very limited. One of the first studies of this type was that of Odhiambo (2009), who finds that, for the case of South Africa in the period 1960-2006, economic growth Granger-causes a decrease in poverty, in such a way that a $1 \%$ increase in the rate of economic growth reduces poverty between 0.6 and 0.9 percent.

Mulok et al. (2012), using an Autoregressive Distributed Lags (ARDL) model for the case of Malaysia, find that there is an inverse correlation between poverty and economic growth. Stevans and Sessions (2008), using a VECM for the case of the United States, also find that there is an inverse relationship between the rate of economic growth and the poverty rate.

In the case of Nindi and Odhiambo (2015) find that economic growth does not Granger-causes poverty reduction, neither in the short nor in the long term. The authors point out that this lack of effect of economic growth on the reduction of poverty can be explained by the highly unequal distribution of income prevailing in the country. Nyasha et al. (2017) find that, in the case of Ethiopia, there is a bidirectional causal relationship between economic growth and poverty reduction, but that this relation is valid only for the short term, since in the long term no causality of any kind is found. Abosedra et al. (2016) also find, for the case of Egypt, a bidirectional causal relationship between both variables, such as Rehman and Shahbaz (2014) did for the case of Pakistan for the period 1972-2011.

The literature on the topic of the relationship between economic growth and poverty in the case of Mexico is quite scarce. We were able to find only three studies that analyze exclusively the case of Mexico and another one (Fosu 2017) which estimates elasticities for many countries, among them Mexico. The first of these studies was carried out by Hernández-Laos (2010), who analyzes the effects of economic growth and the distribution of income over poverty in the period 1992-2006, finding an inverse relationship between these two variables. The second study was conducted by Esquivel (2015), who finds that economic growth in Mexico from 1992 onwards did not reduce poverty.

A third study, by Campos Vázquez and Monroy-Gómez-Franco (2016) analyzes the relationship between economic growth in Mexico and poverty at the state level. In the long run (2000-2012 period), the authors find that economic growth did not translate into significant poverty decreases. However, in the short run (2005-2014 period) the authors find that there is an inverse relationship between 
economic growth and poverty, although only for some states. At the national level, the authors find a unitary elasticity between poverty and growth.

In the most recent study, Fosu (2017) estimates that the poverty-growth elasticity for Mexico is -3.7 with the poverty line of $\$ 1.25$ per person per day and -2.2 for a poverty line of $\$ 2.5$ per person per day.

\section{Data}

The definition of poverty adopted in this study is based on the per capita consumption of the household. The use of this variable as a proxy for poverty is because the poverty count data for the case of Mexico are available only biennially since 1984 which, if used in the econometric model would substantially reduce the sample to only fifteen observations (instead of 57 if we use the proxy variable). Per capita consumption of the household as a proxy for poverty has been used by many authors, including, for example Ho and Iyke (2018); Odhiambo (2009); Uddin et al. (2014), among others. Specifically, in the case of Mexico it is worth noting that the correlation coefficient between per capita household's consumption and the poverty headcount ratio using the World Bank's intermediate poverty line ( $\$ 5.50$ dollars per day per person, measured at 2011 international prices) is -0.82 , which suggests that this variable can be used as a good proxy for poverty.

The period covered in the analysis is 1960-2016. All the data were transformed into logarithms to correct possible heteroscedasticity problems in the series. The variable of GDP per capita was obtained from World Development Indicators (World Bank 2016) and is expressed in constant national currency units (Mexican constant pesos). The per capita household consumption variable was obtained from this same source and is also expressed in units of constant local national currency.

\section{Econometric Model}

The main objective of this study is to investigate the possible correlation and causality between the variables economic growth and poverty reduction in Mexico for the period 1960-2016. For this, we will first check the stationarity properties of the series through the Banerjee, Lumsdaine, and Stock test (Banerjee et al. 1992) in order to consider the possibility of a structural change in the variables during this long period. Subsequently, we will use the cointegration test proposed by Gregory and Hansen (1996) to determine if the series are cointegrated even in the possible presence of structural change in any of the variables considered in the model. Then, with a dummy variable to represent the possible structural change after a given year, we will estimate a VECM to estimate the short- and long-term elasticities of growth over poverty and vice versa. Finally, we will carry out a Granger causality test to determine if there is a relation of causality between these variables.

Thus, the econometric model to be developed in the paper is a VECM, which can be described as follows:

$$
\begin{aligned}
& \Delta \text { LGDPPC }_{t}=\alpha_{0}+\sum_{\mathrm{i}=1}^{\mathrm{n}} \alpha_{1 \mathrm{i}} \Delta \mathrm{LGDPPC}_{\mathrm{t}-\mathrm{i}}+\sum_{\mathrm{i}=1}^{\mathrm{n}} \alpha_{2 \mathrm{i}} \Delta \mathrm{LPOV}_{\mathrm{t}-\mathrm{i}}+\alpha_{3} \mathrm{LGDPPC}_{\mathrm{t}-1}+\alpha_{4} \mathrm{LPOV}_{\mathrm{t}-1}+\alpha_{5} \mathrm{D}_{\mathrm{t}}+\mu_{1 \mathrm{t}} \\
& \Delta \mathrm{LPOV}_{\mathbf{t}}=\beta_{0}+\sum_{\mathrm{i}=1}^{\mathrm{n}} \beta_{1 \mathrm{i}} \Delta \mathrm{LGDPPC}_{\mathrm{t}-\mathrm{i}}+\sum_{\mathrm{i}=1}^{\mathrm{n}} \beta_{2 \mathrm{i}} \Delta \mathrm{LPOV}_{\mathrm{t}-\mathrm{i}}+\beta_{3} \mathrm{LGDPPC}_{\mathbf{t}-1}+\beta_{4} \mathrm{LPOV}_{\mathrm{t}-1}+\beta_{5} \mathrm{D}_{\mathbf{t}}+\mu_{2 \mathrm{t}}
\end{aligned}
$$

where:

LGDPPC $=$ Natural logarithm of real gross domestic product per capita

LPOV = Natural logarithm of household consumption expenditure

$\mathrm{D}=$ Dummy variable

$\mu=$ Disturbance term 


\section{Empirical Findings}

\subsection{Stationarity Tests}

Since the period considered in the analysis is very long, covering more than 55 years, we carried out stationarity tests which consider the possibility that a structural change has occurred in any of the years. We did this through the Banerjee, Lumsdaine, and Stock test (Banerjee et al. 1992), whose results are shown in Table 1. It can be seen there that the variables are not stationary in levels but that they are stationary in differences, even in the presence of a structural change in both series.

Table 1. Banerjee, Lumsdaine, and Stock Breakpoint Unit Root Test.

\begin{tabular}{cccccc}
\hline Variable & t-Statistic & $p$-Value & Lags & Unit Root & Stationarity \\
\hline LGDPPC & -2.871216 & 0.9430 & 1 & Yes & Not stationary \\
D.LGDPPC & -7.144216 & $<0.01^{* * *}$ & 0 & No & Stationary \\
LPOV & -3.643438 & 0.6015 & 2 & Yes & Not stationary \\
D.LPOV & -6.556915 & $<0.01^{* * *}$ & 0 & No & Stationary \\
\hline
\end{tabular}

Notes: (1) D denotes the first difference operator; (2) ${ }^{* * *}$ indicates significance at the $1 \%$ level. Source: Own estimates.

\subsection{Cointegration Tests}

Because the cointegration test of Johansen is not robust in the presence of possible structural changes in the series and given that this situation is highly likely when the period covered in the analysis is long, as in this case (56 years, from 1960 to 2016), we decided to use the cointegration test proposed by Gregory and Hansen (1996), whose results are shown in Table 2, where it can be observed that the Augmented Dickey-Fuller (ADF)* and $\mathrm{Zt}^{*}$ tests reject the null hypothesis that there is no cointegration between poverty and economic growth, detecting a break in 1978 according to the same test. The structural change detected this year may be due to the Mexican oil boom that occurred between 1978 and 1981. During this period, the Mexican economy expanded at a rate of 9 percent per year on average, while GDP per capita grew at a rate of 6.5 percent, more than double the rate experienced in the preceding period (1961-1977). Therefore, to account for this structural change, we included a dummy variable for this year in the VECM whose results are presented below.

Table 2. Gregory-Hansen Test for Cointegration with Regime Shifts.

\begin{tabular}{ccccccc}
\hline Testing Procedure & Test Statistic & Breakpoint & Date & \multicolumn{2}{c}{ Asymptotic Critical Values } \\
\hline & & & & $\mathbf{1 \%}$ & $\mathbf{5 \%}$ & $\mathbf{1 0} \%$ \\
\hline ADF & -5.78 & 19 & 1978 & -6.02 & -5.5 & -5.24 \\
$\mathrm{Zt}$ & -5.83 & 19 & 1978 & -6.02 & -5.5 & -5.24 \\
$\mathrm{Z} \alpha$ & -43.36 & 19 & 1978 & -69.37 & -58.58 & -53.31 \\
\hline
\end{tabular}

Source: Own estimates.

\subsection{Long-Run Elasticities}

Using the Johansen method and including the dummy variable for the structural change created after 1978, we estimated a VECM and taking advantage of the fact that the variables included in the model are expressed in logarithms, it is possible to directly estimate the long-term elasticities, which are shown in Table 3. It can be seen that, in the long run, economic growth has a positive and statistically significant effect on the reduction of poverty (increase in per capita consumption) and that, in turn, poverty reduction (increase in per capita consumption) positively affects economic growth. 
Table 3. Long-Run Elasticities.

\begin{tabular}{ccc}
\hline \multirow{2}{*}{ Endogenous Variables } & \multicolumn{2}{c}{ Exogenous Variables } \\
\cline { 2 - 3 } & LGDPPC & LPOV \\
\hline \multirow{2}{*}{ LGDPPC } & - & $0.421^{* * *}$ \\
& & $(0.069)$ \\
\hline \multirow{2}{*}{ LPOV } & $2.373^{* * *}$ & - \\
\hline
\end{tabular}

Notes: (1) Standard errors in parenthesis; (2) ${ }^{* * *}$ indicates significance at the $1 \%$ level. Source: Own estimates.

The estimated elasticities indicate that a $1 \%$ increase in economic growth leads to a $2.4 \%$ increase in per capita consumption (decrease in poverty) and a $1 \%$ increase in per capita consumption (decrease in poverty) results in a 0.4 percent increase in the rate of economic growth.

The estimated growth elasticity of poverty $(-2.4)$ found in this paper is very similar to the one obtained by Fosu (2017), who, in a sample of 123 developing countries for the period 1981-2007, found an elasticity of -2.3 . For the case of Mexico, the same author estimated a growth elasticity of poverty of -3.7 with a poverty line of $\$ 1.25$ per person per day and a growth elasticity of poverty of -2.2 when the poverty line used is $\$ 2.5$ per person per day. Our estimate of the growth elasticity of poverty is also very similar to that found by Adams (2004) who estimated an elasticity of -2.8 for a sample of 60 developing countries. However, it should be noted that the findings of these authors are based on the use of the poverty headcount, not in per capita consumption as it is done in this paper.

\subsection{Short-Run Elasticities}

The VECM developed in this paper also allows estimating the short-term interactions between economic growth and poverty. In Table 4 we can see that economic growth has a positive and statistically significant effect on reducing poverty also in the short term and vice versa. The positive sign of the break dummy coefficient indicates an increase both in per capita GDP as in per capita household consumption (decrease in poverty) after 1978.

Likewise, it can be observed in Table 4 that the coefficient of the error correction term (ECT) in both equations is negative and statistically significant at a level of significance of one percent, which indicates that the variables converge towards equilibrium in the long term.

Table 4. Short-Run Elasticities.

\begin{tabular}{|c|c|c|}
\hline \multirow[t]{2}{*}{ Exogenous Variables } & \multicolumn{2}{|c|}{ Endogenous Variables } \\
\hline & D.LGDPPC & D.LPOV \\
\hline D.LGDPPC $_{(\mathrm{t}-1)}$ & $\begin{array}{c}0.453^{* * *} \\
(0.158)\end{array}$ & $\begin{array}{c}0.883^{* * *} \\
(0.296)\end{array}$ \\
\hline $\operatorname{D.LGDPPC}_{(\mathrm{t}-2)}$ & $\begin{array}{c}0.329 * * \\
(0.164)\end{array}$ & $\begin{array}{c}0.451 \\
(0.308)\end{array}$ \\
\hline $\operatorname{D.LPOV}_{(\mathrm{t}-1)}$ & $\begin{array}{c}-0.195^{*} \\
(0.100)\end{array}$ & $\begin{array}{l}-0.292 \\
(0.187)\end{array}$ \\
\hline $\operatorname{D.LPOV}_{(\mathrm{t}-2)}$ & $\begin{array}{c}-0.300^{* * *} \\
(0.092)\end{array}$ & $\begin{array}{c}-0.383^{* *} \\
(0.173)\end{array}$ \\
\hline DUMMY1978 & $\begin{array}{c}0.0748^{* * *} \\
(0.021)\end{array}$ & $\begin{array}{l}0.076^{*} \\
(0.040)\end{array}$ \\
\hline CointEq & $\begin{array}{c}-0.549 \text { *** } \\
(0.114)\end{array}$ & $\begin{array}{c}-0.568^{* * *} \\
(0.213)\end{array}$ \\
\hline Constant & $\begin{array}{c}-0.039 * * \\
(0.017)\end{array}$ & $\begin{array}{l}-0.038 \\
(0.031)\end{array}$ \\
\hline
\end{tabular}

Notes: (1) D denotes the first difference operator; (2) Standard errors in parenthesis; (3) ${ }^{* * *}, * *$ and * indicate significance at the $1 \%, 5 \%$ and $10 \%$ levels, respectively. 


\subsection{Granger Causality Test}

The results of the Granger causality test shown in Table 5 indicate that there is a bidirectional relationship of causality between both series, that is to say, economic growth Granger-causes a decrease in poverty and that the reduction of poverty Granger-causes economic growth, in both cases with a high level of significance of one percent.

Table 5. Granger Causality Tests.

\begin{tabular}{ccc}
\hline Causality Direction & Chi-Square Test Statistic & Probability \\
\hline POV $\rightarrow$ PCGDP & $12.323^{* * *}$ & 0.002 \\
PCGDP $\rightarrow$ POV & $9.859^{* * *}$ & 0.007 \\
\hline Note: $* * *$ indicate significance at the $1 \%$ level. Source: Own estimates.
\end{tabular}

\section{Conclusions}

The relationship between poverty and economic growth has been widely discussed in the economic development literature during the past few decades. Since the consensus of that literature is that there exists an inverse relationship between economic growth and poverty, in the last two decades the discussion has centered on measuring the effect of economic growth on the reduction of poverty. However, most of this literature has been based on cross-sectional studies. Only in recent years some literature making use of modern time-series techniques has emerged and has been applied to several countries but not for Mexico. To our knowledge, this is the first paper that applies these techniques to the Mexican case.

In the period under analysis in this study (1960-2016) per capita household consumption in Mexico grew at an average annual rate of 2.5 percent, while GDP per capita grew at an average annual rate of 1.8 percent. At the same time, in the period for which there is poverty headcount data (1984-2016), the poverty rate decreased 11.3 percentage points, from 22.5 per cent of the population in 1984 to 11.2 per cent in 2016. This information, coupled with the fact that the Gini coefficient fell from 0.49 in 1984 to 0.43 in 2016, could be indicative of the existence of an inverse relationship between economic growth and poverty in Mexico.

Thus, the objective of this study was to analyze the relationship between poverty and economic growth in Mexico, through a cointegration analysis for the period 1960-2016. The Gregory-Hansen cointegration test confirmed the existence of a long-run equilibrium relationship between the reduction of poverty and economic growth, both in the short run as is in the long-run. In the long run, it was found that a $1 \%$ increase in economic growth leads to a $2.4 \%$ increase in per capita consumption (and therefore to poverty reduction). These results are very similar to the estimates obtained by Fosu (2017) and Adams (2004). In addition, using the Granger causality test it was found that there is a bidirectional causality relationship between the reduction of poverty and economic growth in Mexico. These findings add to the empirical literature on the relationship between these important variables, particularly to the literature for single countries and based on the use of time-series analysis.

The results found in this article indicating that there exists an inverse relationship between economic growth and poverty in Mexico suggest that the country should continue to deepen its efforts to increase the rate of economic growth to reduce poverty. In this direction, the structural reforms carried out in recent years could contribute to increase the rate of economic growth and, consequently, to reduce poverty in the country.

For future research it is recommended to analyze the effects of economic growth by economic sectors, as well as to determine how much of the poverty reduction has been due to economic growth and how much to the social policies to decrease poverty established by the Mexican government since the 1980s. 
Funding: This research received no external funding.

Conflicts of Interest: The authors declare no conflicts of interest.

\section{References}

Abosedra, Salah, Muhammad Shahbaz, and Kishwar Nawaz. 2016. Modeling Causality Between Financial Deepening and Poverty Reduction in Egypt. Social Indicators Research 126: 955-69. [CrossRef]

Adams, Richard H. 2004. Economic growth, inequality and poverty: Estimating the growth elasticity of poverty. World Development 32: 1989-2014. [CrossRef]

Alvaredo, Facundo, and Leonardo Gasparini. 2015. Recent trends in inequality and poverty in developing countries. In Handbook of Income Distribution. Amsterdam: Elsevier. [CrossRef]

Banerjee, Anindya, Robin L. Lumsdaine, and James H. Stock. 1992. Recursive and Sequential Tests of the Unit-Root and Trend-Break Hypotheses: Theory and International Evidence. Journal of Business \& Economic Statistics 10: 271-87. [CrossRef]

Besley, Timothy, and Robin Burgess. 2003. Halving Global Poverty. Journal of Economic Perspectives 17: 3-22. [CrossRef]

Bourguignon, Francois. 2003. The Growth Elasticity of Poverty Reduction: Explaining Heterogeneity across Countries and Time Periods. In Inequality and Growth: Theory and Policy Implications. Cambridge: MIT Press.

Bourguignon, Francois. 2004. The Poverty-Growth-Inequality Triangle. New Delhi: Indian Council for Research on International Economic Relations.

Campos Vázquez, Raymundo M., and Luis A. Monroy-Gómez-Franco. 2016. La relación entre crecimiento económico y pobreza en México. Investigación Económica 75: 77-113. [CrossRef]

Dollar, David, and Aart Kraay. 2002. Growth is Good for the Poor. Journal of Economic Growth 7: 195-225. [CrossRef]

Esquivel, Gerardo. 2015. Desigualdad Extrema en México: Concentración del Poder Económico y Político. Ciudad de México: Oxfam México.

Ferreira, Francisco H. G., and Martin Ravallion. 2011. Poverty and Inequality: The Global Context. In The Oxford Handbook of Economic Inequality. Oxford: Oxford University Press. Available online: http:/ /www.oxfordhandbooks.com/view/10.1093/oxfordhb/9780199606061.001.0001/oxfordhb9780199606061-e-24 (acceseed on 28 September 2018).

Fosu, Augustin Kwasi. 2017. Growth, inequality, and poverty reduction in developing countries: Recent global evidence. Research in Economics 71: 306-36. [CrossRef]

Gregory, Allan W., and Bruce E. Hansen. 1996. Residual-based tests for cointegration in models with regime shifts. Journal of Econometrics 70: 99-126. [CrossRef]

Hernández-Laos, Enrique. 2010. Crecimiento, Distribución y Pobreza (1992-2006). Edited by C. M. Aparicio, Ricardo Villarespe and Verónica Urzúa. Pobreza en México: Magnitud y Perfiles, pp. 43-97.

Ho, Sin-Yu, and Bernard Njindan Iyke. 2018. Finance-growth-poverty nexus: A re-assessment of the trickle-down hypothesis in China. Economic Change and Restructuring 51: 221-47. [CrossRef]

Kakwani, Nanak, and Ernesto M. Pernia. 2000. What is pro-poor growth? Asian Development Review 18: 1-16. [CrossRef]

Mulok, Dullah, Mori Kogid, Rozilee Asid, and Jaratin Lily. 2012. Is economic growth sufficient for poverty alleviation? Empirical evidence from Malaysia. Cuadernos de Economía 97: 26-32. [CrossRef]

Nindi, Angelique, and Nicholas M. Odhiambo. 2015. Poverty and Economic Growth in Swaziland: An Empirical Investigation. Managing Global Transitions 13: 59-74.

Nyasha, Sheilla, Yvonne Gwenhure, and Nicholas M. Odhiambo. 2017. Poverty and Economic Growth in Ethiopia: A Multivariate Causal Linkage. The Journal of Developing Areas 51: 343-59. [CrossRef]

Odhiambo, Nicholas M. 2009. Finance-growth-poverty nexus in South Africa: A dynamic causality linkage. The Journal of Socio-Economics 38: 320-25. [CrossRef]

Ravallion, Martin. 1995. Growth and poverty: Evidence for developing countries in the 1980s. Economics Letters 48: 411-17. [CrossRef]

Ravallion, Martin. 2001. Growth, inequality and poverty: Looking beyond averages. World Development 29: 1803-15. [CrossRef]

Ravallion, Martin. 2012. Why don't we see poverty convergence? American Economic Review 102: 504-23. [CrossRef] 
Ravallion, Martin, and Shaohua Chen. 1997. What Can New Survey Data Tell Us about Recent Changes in Distribution and Poverty? The World Bank Economic Review 17: 357-82. [CrossRef]

Ravallion, Martin, and Gaurav Datt. 2002. Why has economic growth been more pro-poor in some states of India than others? Journal of Development Economics 68: 381-400. [CrossRef]

Rehman, Ijaz Ur, and Muhammad Shahbaz. 2014. Multivariate-based Granger causality between financial deepening and poverty: The case of Pakistan. Quality and Quantity 48: 3221-41. [CrossRef]

Seers, Dudley. 1969. The Meaning of Development. New Delhi: IDS Communication, p. 44.

Stevans, Lonnie K., and David N. Sessions. 2008. The Relationship Among Poverty, Economic Growth, and Inequality Revisited. Journal of Income Distribution 17: 5.

Thorbecke, Erik. 2013. The interrelationship linking growth, Inequality and poverty in Sub-Saharan Africa. Journal of African Economies 22: i15-i48. [CrossRef]

Uddin, Gazi Salah, Muhammad Shahbaz, Mohamed Arouri, and Frédéric Teulon. 2014. Financial development and poverty reduction nexus: A cointegration and causality analysis in Bangladesh. Economic Modelling 36: 405-12. [CrossRef]

World Bank. 2016. World Development Indicators 2016. Washington: World Bank. [CrossRef]

(C) 2018 by the author. Licensee MDPI, Basel, Switzerland. This article is an open access article distributed under the terms and conditions of the Creative Commons Attribution (CC BY) license (http:/ / creativecommons.org/licenses/by/4.0/). 